\title{
AUDUBON COUNTY'S "TROUBLESOME GANG"
}

\section{By Judge H. J. MANTZ}

The data which the writer has used in this article has been gathered from various sources-newspaper accounts, letters written about the time of some of the incidents set forth, court records, talks many years later with some of the active participants, and some from personal observations. Some incidents are included which took place in the early history of the county. From them one would conclude that crime does not pay, and that the patience and forbearance of peaceable citizens have limitations; also that ordinarily peaceful citizens sometimes use extra-judicial activities to curb crime, and frequently with wholesome results.

The incidents recited were given much publicity, and the impression got about that the people of Audubon county were a law-breaking, reckless type, and on slight provocation would use what might be termed "frontier justice". However, in fact they were peaceable and law-abiding as a general rule. For some years crime had been on the increase and frequently was unpunished. In 1884, following the last episode recited below, there were but three murders in the county. Thereupon, the people of the county concluded that crime should not go unpunished and to insure their own safety and that of the community took drastic action.

Audubon county as laid out by legislative act was named for that eminent naturalist and ornithologist, John James Audubon, whose studies of bird life were an outstanding contribution to natural history. To a large extent the county was prairie with some timber along the streams and with some large groves in the south and east parts. It had been crossed by various trails made in the westward journey by the Mormons. The county has no large rivers; the largest, the Botna, flows to the south and about the center of the county. Into this river flow some smaller streams-Blue Grass near the present city of Audubon, David's creek near Exira 
and the Troublesome stream which has its source in the western part of Guthrie county and flows to the south and then west through the southeast part of the county.

\section{SETTLERS CAME IN 1851}

The first permanent settler was Nathaniel (Natty) Hamlin, who came with his family in 1851, and built the first log cabin near the Troublesome. This stream was so named because of the difficulty in crossing, it then having quite a volume of flowing water. Shortly following the time Hamlin came other families followed and for the most part settled in the southern and eastern part of the county. Because of the availability of water, $\operatorname{logs}$ and fuel, most of them settled in the timber and close to the streams.

Among the settlers who came shortly after Hamlin was Dr. Samuel Ballard, a physician, who later became prominent in state affairs. There also came two brothers, J. A. and I. P. (Ike) Hallock. Ballard sought to secure large tracts of land. At that time the county was unorganized and much of the land unsurveyed. The settlers staked out claims and organized in groups to protect such claims from claim jumpers and land speculators, and rules were established limiting the holding of any one claimant. Due to the fact that Ballard was a physician an exception was made in his case. Ike Hallock secured a large tract of land near the present town of Brayton and actively engaged in farming and stock raising and became one of the first cattle feeders of the county. He located his home east of Brayton and on the old stage route.

Most of the early settlers came from the south and the border states and many of them were southern sympathizers. A considerable group located near the Troublesome river and in time became known as the "Troublesome Gang". This group did little to develop the country and their principal activities seem to have been hard-drinking and horse racing. Soon stock, grain and other property became missing and there were indica- 
tions that this was due to the gang, which committed various depredations and to such an extent that they terrorized the other settlers.

Many of the gang members were rough, reckless and unscrupulous -in fact, most of the settlers feared them, knowing that if their ill-will was aroused dire consequences would result, such as buildings burned, violence and forcible intimidations. As time went on the gang became bolder and finally a real menace to life and property. There exists evidence of the fact that the members of the gang had some connection with the James brothers of Missouri and that some were active in the holdup and robbery of a Rock Island passenger train near Adair, Iowa.

\section{DEPREDATIONS EASILY TRACED}

Settlers who lost stock feared to attempt recovery or prosecution, knowing that the gang would stop at nothing in order to secure revenge. Cattle belonging to Ike Hallock began to disappear. Suspicion pointed toward the Troublesome gang. Against the advice of friends, Hallock, a man of courage and determination, decided to take action. A search was made, some of his stock was found in the possession of some of the gang members, and events showed that some had been sold and gotten out of the country. This act on the part of Hallock enraged the gang and they freely and openly boasted that they would "get" Hallock. His friends became apprehensive for his safety. His brother, John A. Hallock, with three sons, left Audubon county a few years before and went to Colorado. One of the sons went to Wyoming and became a cowboy. He soon gained the reputation of being a dead shot-then considered quite a valuable acquisition in a territory where, according to the frontier code, "the law was at the belt." Ike, on the advice and solicitation of his friends and family, induced the cowboy nephew to return to Audubon county, ostensibly as a herdsman, but in reality as a bodyguard for his uncle. Sometime later the leader of the gang and two others traveling by sled, went to Exira and while there pro- 
ceeded to terrorize its inhabitants, by hard drinking, threats and occasional discharge of firearms. They left the town in the gathering dusk, drunken and profane, with a waving of firearms. A group of citizens gathered on a sidewalk along the street. Suddenly the gang leader fired a shotgun in the direction of the group causing them to scatter for safety, and as they did there was the sharp report of a revolver. The driver of the sled let out a wild yell and fell backward into the sled. The gang leader yelled "You _ _ you have killed ; you will pay for this." The team took fright and ran away. The gang figured that the cowboy Hallock did the shooting. While he was said to have been there no one directly accused him of firing the fatal shot. This shooting simply intensified the activities of the gang and some of it's members openly avowed that they not only would get Ike, but also his nephew.

Not long thereafter the nephew was working in the home feed lot with a team putting corn in the feed bunks. Suddenly three riders, heavily armed, rode into the lot. The gang leader came first. They rode in yelling and shouting, "You we are here to get you." Hallock ran around to the head of his team. He did not hesitate. He shot two from their horses and winged the third as he beat a hurried retreat. The two were instantly killed. The sheriff called a coroner's jury and that body heard the evidence. Its solemn verdict was "justifiable homicide."

\section{Wiota RESISTED GANG'S ATTACK}

To some extent this affair lowered the prestige of the gang; but their local activities were not ended. Some of them became incensed over the actions of various citizens of the neighboring town of Wiota and it was decided to "shoot up the town" in approved gang style. Some of the gang imbibed considerable liquor and told of the plan and when it was to be carried out. The news was relayed to Wiota and the citizens made preparations to receive them. The road into the town passed by some corn cribs and the citizens armed with all available wea- 
pons, awaited the coming. Soon members of the gang came in with horses running, firing their guns, and shouting profanity. They didn't get far beyond the corn cribs. Two of them were shot from their horses, stone dead, and several others were wounded and escaped. Again the coroner's jury verdict-"justifiable homicide".

The late Howard J. Clark, a prominent attorney in Des Moines, then lived with his parents just east of the old town of Oakfield. Just before his death in 1939 he told the writer of the Hallock shooting; also, that at Wiota. He said that the day following the shooting at Wiota the father of one of those killed drove by the Clark home. Howard and his father were down at the road. They knew the father. The dead son was in a rough box in his lumber wagon. Clark, Sr. remarked, "It must be hard to take a son home under these conditions", and the father remarked, as he drove on: "Well, mother and I will now know where he is at nights."

Following these two episodes other gang members saw the handwriting on the wall and moved to other placessome to Wyoming and Montana, and the Black Hills. Later reports came that many of them there died as they had lived-with their boots on.

Ike Hallock lived at Oakfield until he died, a highly respected citizen. His cowboy nephew went to Colorado and for many years worked for the D. \& R. G. Ry. Co. He died a few years ago. A few years before his death the writer met him while visiting with a relative in Grimison, Colorado. He talked freely of his early life in Audubon county, but said nothing as to the stirring event in Exira and later in the feed lot.

\section{SON AND SON-IN-LA'W HeLPED HANG MAN}

In the early eighties an atrocious and shocking crime was committed at the farm home of one Jellison, located a few miles east of the present city of Audubon. A middle-aged couple, Jellison and wife, lived there. One night three men broke into the farm home and forcibly 
dragged Jellison from his bed, took him out into the yard and hanged him to a tree. His wife later gave the alarm and always claimed that she did not have any idea who had committed the dastardly deed. Some people questioned this, as there had been some dissension in the family between Jellison and a couple of his sons-in-law. Henry Herbert, then sheriff, was called. When the body of Jellison was cut down there was found clutched in his hand an overcoat button. Because of the family troubles suspicion was cast upon the sons-in-law, Smythe and Wilson, who lived in the vicinity of Coon Rapids.

Jellison was buried in an Audubon cemetery. At the funeral Sheriff Herbert noticed that one of the sonsin-law was wearing an overcoat with one button missing, and that the one clutched in the dead man's hand was similar to those remaining on the overcoat. He arrested them at that time. A son of the deceased was also arrested. The son confessed, claiming that Smythe and Wilson forced him to go with them to kill his father to avenge an offense which they claimed had been committed by the father upon the wife of Wilson. The three were indicted for the crime, the charge being that of murder. A local newspaper wrote up the affair in all its lurid details, with the son's confession; also that he later had repudiated it and that all were to stand trial. The attorneys for the defendants moved for a change of venue, claiming that in view of the widespread publicity and public clamor a fair trial could not be had in Audubon county. This was argued to the court with no immediate ruling.

Public interest was whipped to a fever heat-the nature of the crime, the confession, its repudiation, and the heavy expenses to be incurred by the county to prosecute. The judge to whom the motion for change of venue was submitted did not return but mailed an order that the case be tried in another county. A few nights later an organized group took possession of the town, posting guards at roads and other points and forcing citizens to remain indoors. Then they marched to the jail and 
demanded of the sheriff, who lived upstairs, that he turn over the Jellison killers. He refused and attempted to spread the alarm by shooting from the upstairs window. Shots from the crowd forced him inside. The crowd, using a heavy wooden timber as a battering ram, crashed into the jail and Wilson and Smythe were shot and killed. The son, Cicero Jellison, was taken to a small park bandstand and there hanged. The next morning citizens found Smythe and Wilson hanging to the jail fence, with Cicero Jellison hanging in the bandstand.

The morning following the father of the writer was working on a road culvert near the home. While doing so two men, neighbors, riding horseback, came from the direction of Audubon. They stopped and one of them addressing father, said: "Sam, those Jellison killers got a change of venue." Father inquired, "Where to". The rider clicked to his horse and answered "to hell" and rode on. The bridge work ceased; father and the hired man at once took the team and drove to town. That was the writer's first experience with legal phraseology, "change of venue."

\section{PolK City Tragedy Avenged}

Another incident happened about the same time and like the other two, had a tragic ending. Sometime in the early eighties two men in an attempted holdup shot a merchant in Polk City, Iowa, a small place northwest of Des Moines. After the shooting they fled by horseback to the west. The alarm was given and roads were guarded. A day or two later a farmer living northeast of Audubon, Sam McGill, by name, was in his barn currying his horses when two men came into the barn and demanded a team of horses. Both were armed and McGill made no resistance. They took his team and started southwest and passed the town of Audubon on the north and were observed hurrying their horses along.

Later in the afternoon a contractor named Hunter was building a highway bridge near Elkhorn, Shelby county, 
just over the line from Audubon county. Two horsemen driving hard some jaded horses approached and seeing the bridge being built forced the horses into the stream. One horse was so badly exhausted that it went down and could not get up. Its rider ordered the other to halt and both got on the other horse, and rode westward. The bridge workers noted that one of the men was heavily armed. Thinking that something was wrong the alarm was given. About that time word was received to be on the lookout for the pair. The two rode into an adjacent wooded area known as "Buck's Grove." The next morning various groups entered the grove. One of these, a man from Marne, Iowa, was shot in the head and killed, while a man named Hallock from Oakfield was seriously injured. It was deemed safer to guard the surrounding area and wait for more men. Farmers from all of the country about armed themselves and went and joined in the man hunt.

About noon of the next day two men from Atlantic were waiting along a small wooded stream when they saw one of the hunted pair come down the other side carrying in his hand a large revolver. The Atlantic men were armed with guns loaded with buckshot. Both fired and the man with the revolver went down, mortally injured. A crowd gathered and carried him to some high ground and placed him in a spring wagon. A physician gave him some attention until a cry went up that the other fellow had been caught. All rushed in that direction and the owner of the vehicle pushed the wounded man out and drove away. At the edge of the woods a crowd of approximately 500 nearly all armed, had the prisoner. He was a young man, barely of age and unarmed. A rope was placed about his neck and the whole aggregation started to run to a large iron girder bridge about an eighth of a mile away. The crowd stopped at the bridge with the purpose of hanging the prisoner. He was asked who he was and he said that he was from Ohio and that he had a mother living there. He said that the older man had led him into the commission of 
crimes. When he made that statement a howl of derision went up with cries of "shoot him-hang him." There were a number of officers in the crowd, but they could do little. The prisoner was asked if there was anything he wanted. He said he wanted something to eat and that he hadn't eaten for two days. The crowd finally agreed to get him some food and someone was sent to a neighboring house and soon returned with some milk, cheese and crackers. Years later, one of the crowd told the writer that the prisoner seemed the coolest man there and ate the lunch like a famished man. A lawyer from Audubon, John M. Griggs, asked if he wanted to write to his mother and he answered that he did and wrote her, telling his situation and expressing his sorrow for the grief he had caused her.

\section{THE SHERIFF'S ADROITNESS}

About that time Sheriff Rainbow of Shelby county, an old plainsman, began to talk to the crowd about this youth and that they should let the law take its course. The friends of the deceased Marne man were vociferous and violent in demands that the prisoner be hanged. Finally, Rainbow drove a buggy upon the bridge and placed the prisoner in it and then called for the crowd to vote as to whether a hanging should take place or the prisoner be given to the custody of the law. The bridge was on an east and west road, the west toward Harlan, the county seat of Shelby county. Rainbow asked that those who wanted hanging gather at the east end of the bridge, the others, to the west. When they were so divided, Rainbow stood in the rear end of the vehicle behind the prisoner. He called to the driver to drive to the west, and at the same time pulled out two six shooters and announced that he would shoot anyone who tried to stop him. None did, as they knew Rainbow was a man of courage and with iron nerve. He took the prisoner to Harlan and placed him in the county jail. A few nights later a mob stormed the jail, took the prisoner out and hanged him and then riddled his 
body with bullets. It was believed that the friends of the Marne man were the prime movers of the mob.

Attorney Griggs, some forty years later, in speaking of the event, told the writer that he never sent the note to the mother; as it would only add to her grief. It was reported that they never knew the name of the other criminal and that his body was sent to a medical college.

While over two-thirds of a century has gone, still we hear some oldtimers speak of the "Troublesome Gang", the "Jellison lynching", and the man hunt at "Buck's Grove".

\section{GOVERNMENT UNDER CONSTITUTION}

Gov. Stephen Hempstead: I may be permitted to refer to the policy of government, under which we have increased in population and wealth, unsurpassed in the history and settlement of western states, and it must be conceded, that for the high position which we now occupy, as a sovereign state of the American republic, that we are principally indebted to the constitution and laws for that prosperity.

Of the constitution of this state, it may with justice be said, that it is republican in its character, and designed to protect the people against abuse and evils which have crept into the government of other and older states. It prohibits any association or corporation from exercising the privilege of creating paper to circulate as money; it declares that corporations shall not be established by special laws, except for political or municipal purposes; and for all others, that general laws shall be passed for their organization, reserving to every one the privilege of forming companies for the transaction of all lawful business, and limiting state indebtedness in such a manner as to prevent great loss or repudiation. These restrictions, it is believed, have done much to build up this state, and to assure its citizens that they are not to be oppressed by monopolies, bankruptcy, or extraordinary taxation.-Message to Fifth General Assembly of Iowa, December 8, 1854. 
Copyright of Annals of Iowa is the property of State of Iowa, by \& through the State Historical Society of Iowa and its content may not be copied or emailed to multiple sites or posted to a listserv without the copyright holder's express written permission. However, users may print, download, or email articles for individual use. 